\title{
KONSEP PENDIDIKAN MULTIKULTURAL DALAM PENDIDIKAN ISLAM
}

\author{
Febri Santi \\ (Peneliti Magistra Indonesia. Email: febrisantifirosad@gmail.com)
}

\begin{abstract}
Education is actually a study that is able to recognize, is able to accommodate all possibilities, understand heterogeneity, appreciate differences both tribes, nations, especially religion. These aspects are interconnected which orients humanity. This course also aligned with one of the humanitarian orientation of multicultural education in the context of the Qur'an is to seek recognition and understanding of SARA to understand heterogeneity, applying the multicultural nature of education itself. This study uses a qualitative approach phenomenologi.
\end{abstract}

Keywords: Education, Multicultural.

\section{PENDAHULUAN}

Manusia tercipta dibekali dua potensi, yaitu potensi yang berorientasi pada kebaikan dan keburukan (Muhammad Nurdin, 2004). Potensi tersebut menghadapkan manusia pada pola perubahan yang harus dijalani, tentunya pada proses normatifitas yang berorientasi pada ranah kebaikan. Salah satu cara untuk mengembangkan potensi tersebut adalah dengan menempuh jalan yang didalamnya ada tata aturan sistem pendidikan. Pendidikan merupakan sebuah sistem yang mengembangkan segala aspek pribadi dan kemampuan (Muhammad, 2003). Pada jalur pendidikan ada beberapa aspek yang harus dicapai dalam berbagai segi kehidupan. Hal ini meliputi pengembangan segi kehidupan masyarakat, sosial budaya, ekonomi dan politik. Bersedia menyelesaikan permasalahan masyarakat terkini dalam menghadapi tuntutan masa depan dan memelihara sejarah dan kebudayaannya. Hakekatnya pendidikan adalah agen sebuah tradisi yang menjunjung tinggi nilai dan adat istiadat yang mengutamakan musyawarah dalam menyelesaikan permasalahan dan bukan berorientasi pada aspek kapitalisme dan kanibalisme intelektual. Jika memahami dan mengerti permasalahan diatas tentunya kita bisa menilai bahwa pendidikan tidak hanya memihak pada orang atau golongan tertentu.

Salah satu tujuan pendidikan adalah tidak membedakan kelas sosial kemasyarakatan, oleh karena itu diperlukan pendidikan multikultural. Pendidikan multikultural adalah sebuah sistem pendidikan yang berupaya untuk meredam kesenjangan sosial, kelas sosial, kecemburuan sosial dengan mengenalkan dan mensosialisasikan kebersamaan. Orientasi kebersamaan ini paling tidak akan mampu untuk memahami betapa pentingnya menghargai dan menciptakan kebersamaan. Jika kelas sosial masih saja di agungagungkan maka akan timbul kecemburuan sosial. Selama ini kecemburuan sosial sering terjadi di dunia pendidikan khususnya dalam upaya pembenahan sebuah sistem yang akan digunakan dalam rangka pengembangan model pendidikan tersebut (Sudjangi, 2003). 
Kebijakan yang sentralistis dan pengawalan yang ketat terhadap isu perbedaan telah menghilangkan kemampuan masyarakat untuk memikirkan, membicarakan dan memecahkan persoalan yang muncul dari perbedaan. Kekerasan antar kelompok yang meledak secara sporadis di akhir tahun 1990-an di berbagai kawasan di Indonesia menunjukkan betapa rentannya rasa kebersamaan yang dibangun dalam Negara-Bangsa. Betapa kentalnya prasangka antara kelompok dan betapa rendahnya saling pengertian antar kelompok. Konteks global setelah tragedi 11 September dan invasi Amerika Serikat ke Irak serta hiruk pikuk politis identitas di dalam era reformasi menambah lengkapnya persoalan keragaman dan antar kelompok. Pemaknaan secara negatif atas keragaman telah melahirkan penderitaan panjang umat manusia. Paling tidak, telah terjadi 35 pertikaian besar antar etnis di dunia. Lebih dari 38 juta jiwa terusir dari tempat yang mereka huni, paling sedikit 7 juta orang terbunuh dalam konflik etnis berdarah. Pertikaian seperti ini terjadi dari Barat sampai Timur, dari Utara hingga Selatan. Dunia menyaksikan darah mengalir dari Yugoslavia, Cekoslakia, Zaire hingga Ruwanda, dari bekas Uni Soviet sampai Sudan, dari Srilangka, India hingga Indonesia. Konflik panjang tersebut melibatkan sentimen etnis, ras, golongan dan agama.

Merupakan kenyataan yang tak bisa ditolak bahwa bangsa Indonesia terdiri dari berbagai kelompok etnis, budaya, agama. Sehingga bangsa Indonesia secara sederhana dapat disebut sebagai masyarakat "multikultural". Tetapi pada pihak lain, realitas multikultural tersebut berhadapan dengan kebutuhan mendesak untuk merekonstruksi kembali "kebudayaan nasional Indonesia" yang dapat menjadi "integrating force" yang mengikat seluruh keragaman etnis dan budaya tersebut. Perbedaan budaya merupakan sebuah konduksi dalam hubungan interpersonal. Sebagai contoh ada yang orang yang bila diajak bicara dalam mengungkapkan perhatiannya cukup dengan mengangguk-anggukan kepala sambil berkata "uh. huh". Namun dalam kelompok lain untuk menyatakan persetujuan cukup dengan mengedipkan kedua matanya. Dalam beberapa budaya, individu yang berstatus tinggi biasanya yang memprakarsai, sementara individu yang statusnya rendah hanya menerima saja sementara dalam budaya lain justru sebaliknya.

Sudut pandang yang biasa berkembang dalam menyikapi perbedaan identitas yang sering muncul paling tidak ada tiga kelompok: Pertama, pandangan primordialis. Kelompok ini menganggap, perbedaan-perbedaan yang berasal dari genetika seperti suku, ras (dan juga agama) merupakan sumber utama lahirnya benturanbenturan kepentingan etnis maupun agama. Kedua, pandangan kaum instrumentalis. Menurut mereka, suku, agama dan identitas yang lain dianggap sebagai alat yang digunakan individu atau kelompok untuk mengejar tujuan yang lebih besar, baik dalam bentuk materil maupun nonmateril. Konsepsi ini lebih banyak digunakan oleh politisi dan para elit untuk mendapatkan dukungan dari kelompok identitas. Dengan meneriakkan "Islam" misalnya, diharapkan semua orang Islam merapatkan barisan untuk memback up kepentingan politiknya. Oleh karena itu, dalam pandangan kaum instrumentalis, selama setiap orang mau mengalah dari prefence yang dikehendaki elit, selama itu pula benturan antar kelompok identitas dapat dihindari bahkan tidak terjadi. Ketiga, kaum konstruktivis, yang 
beranggapan bahwa identitas kelompok tidak bersifat kaku, sebagaimana yang dibayangkan kaum primordialis. Etnisitas, bagi kelompok ini, dapat diolah hingga membentuk jaringan relasi pergaulan sosial. Karenanya, etnisitas merupakan sumber kekayaan hakiki yang dimiliki manusia untuk saling mengenal dan memperkaya budaya. Bagi mereka, persamaan adalah anugerah dan perbedaan adalah berkah.

Terdapat ruang wacana pada pendapat ketiga tentang multikulturalisme dan pendidikan multikultural sebagai sarana membangun toleransi atas keragaman. Pendidikan yang selama ini diwacanakan diberbagai aktifitas itu adalah pendidikan pada taraf teoritik. Pendidikan yang sebenarnya adalah pendidikan yang mampu mengenal, mampu mengakomodir segala kemungkinan, memahami heterogenitas, menghargai perbedaan baik suku, bangsa, terlebih lagi agama. Selain itu jika menyimak maraknya isu sekitar dua tahun kebelakang yakni jual beli kursi pendidikan, membumbungnya biaya pendidikan dan masih banyak lagi. Ini tentunya akan menjadi cermin bagi kita, bagaimana sebenarnya kebenaran arah dan tujuan pendidikan yang beberapa telah disuarakan. Sebagai upaya meredam berbagai permasalahan di atas pendidikan multikultural naik ke permukaan wacana pendidikan sebagai solusi dalam rangka pemenuhan ketidakpuasan masyarakat terhadap sistem pendidikan yang telah dijalankan. Selain itu pendidikan multikultural juga memiliki landasan filosofis yang cukup mampu untuk mengakomodir kesenjangan dalam pendidikan, budaya, dan agama. Ketiga aspek tersebut saling memiliki keterkaitan yang mengorientasikan pada kemanusiaan. Ini tentunya juga selaras dengan salah satu orientasi pendidikan Multikultural yakni kemanusian Wacana Multikulturalisme dalam konteks Al Quran adalah mengupayakan pengenalan dan pemahaman SARA dalam upaya memahami heterogenitas, yakni menerapkan hakekat pendidikan multikultural itu sendiri. (Ainurrafiq Dawam Emoh, 2003).

Pendidikan Multikultural merupakan sebuah gerakan pembaharuan. Pendidikan dapat mengubah nilai-nilai dasar pendidikan, aturan prosedur, kurikulum, materi pengajaran struktur organisasi dan kebijakan pemerintah yang merefleksikan pluralisme budaya, agama, suku dan lain-lain (Zubaedi, 2004). Sementara itu menurut Ainurrafiq Dawam dalam bukunya Emoh sekolah pendidikan multikultural adalah Proses pengembangan seluruh potensi manusia yang menghargai pluralitas dan heterogenitasnya sebagai konsekuensi keragaman budaya etnis, suku, dan agama. Pendidikan multikultural merupakan model pendidikan yang menawarkan konsep persamaan, menghargai dan menghormati pluralitas dan heterogenitas, menghargai keragaman (budaya, agama, suku, bangsa, etnis). Malik Fajar mendefinisikan Pendidikan Multikultural Sebagai suatu pendekatan progresif untuk melakukan transformasi pendidikan yang secara menyeluruh membongkar kekurangan, kegagalan dan praktik-praktik diskriminatif dalam proses pendidikan. Pendidikan multikultural adalah pendidikan yang sarat dengan nilai-nilai kemanusiaan, nilai-nilai sosial, nilai-nilai kealaman, dan nilai-nilai ketuhanan. Untuk itu orientasi bisnis bagi model pendidikan adalah suatu hal yang sangat absurd dan bertolak belakang. Dengan melihat pengertian diatas maka pendidikan multikultural merupakan sebuah solusi abstraktif dalam rangka mengeliminir segala kemungkinan terburuk 
mengenai lingkup multikultural. Dari beberapa pengertian tentang Pendidikan Multikultural, makna Pendidikan Multikultural merupakan sebuah gerakan pembaharuan yang mengubah semua komponen termasuk mengubah nilai-nilai dasar pendidikan, aturan prosedur, kurikulum, materi pengajaran, struktur organisasi dan kebijakan pemerintah yang merefleksikan pluralisme budaya. Selain itu pendidikan multikultural juga menyebarkan metode budaya perdamaian (Sudarwan Danim, 2003).

Menurut Ahmad D. Marimba (1989) pendidikan Islam adalah bimbingan jasmani dan rohani berdasarkan hukum-hukum agama Islam menuju kepada terwujudnya kepribadian utama menurut ukuran-ukuran Islam. Budaya perdamaian adalah semua nilai, sikap, dan bentuk tingkah laku yang menggambarkan penghormatan pada hidup, penolakan kekerasan dalam semua bentuknya dan komitmen pada prinsip-prinsip kebebasan, keadilan, solidaritas, toleransi, dan pengertian antar bangsa dan antar golongan serta antar menusia perorangan. Sedangkan menurut Abudin Nata (2002) Pendidikan Islam adalah Upaya membimbing, mengarahkan dan membina peserta didik yang dilakukan secara sadar dan terencana agar terbina suatu kepribadian yang utama sesuai dengan nilai-nilai Islami. Pendidikan Islam dalam perspektif multikultural merupakan sebuah hasil pemikiran yang masih memerlukan sebuah evaluator dalam proses konversi dan transformasi ilmu pendidikan.

Kamus Bahasa Indonesia menyebutkan bahwa pendidikan merupakan proses pengubahan sikap dan tingkah laku seseorang atau sekelompok orang dalam usaha mendewasakan kepribadiannya melalui upaya pengajaran dan latihan. Pendidikan berarti pula sebagai pengembangan potensipotensi yang terpendam dan tersembunyi. Dalam bahasa Inggris pendidikan berasal dari kata Education. Sedangkan pendidikan Islam itu menekankan pada pemahaman terhadap Islam sebagai suatu kekuatan yangmemberi hidup bagi suatu peradaban raksasa termasuk didalamnya pendidikan (Hasan Langgulung, 2000). Ahmadi (1992) juga memberikan pengertian pendidikan menurut pandangan Islam, yakni tindakan yang dilakukan secara sadar dengan tujuan memelihara dan mengembangkan fitrah serta potensi (sumber daya) insani menuju terbentuknya manusia seutuhnya (insan kamil) yang sesuai dengan nilai-nilai Islami. Secara garis besar, penelitian ini akan memberikan sebuah apresiasi tentang sebuah konsep Pendidikan Multikultural. Pendidikan Islam yang juga menjadi topik kajiannya di Implementasikan dengan model pendidikan Multikultural. Disana tentu muncul berbagai pemikiran pendidikan yang berbeda dari tokoh yang berbeda. Pada bagian inilah penulis hendak memberikan telaah secara mendalam tentang konsep Pendidikan Multikultural Dan Implementasinya Dalam Pendidikan Islam. Dalam penelitian ini, yang dimaksud dengan pendidikan Islam adalah pendidikan (lembaga) dimana titik beratnya terletak pada internalisasi nilai iman, Islam dan ihsan dalam pribadi peserta didik yang berilmu pengetahuan luas.

\section{METODE PENELITIAN}

Untuk memperoleh data dan informasi yang diperlukan, maka penelitian ini menggunakan metode kualitatif dengan 
pendekatan phenomenologi, yakni pendekatan yang mengemukakan bahwa objek ilmu tidak terbatas pada yang empirik (sensual), melainkan mencakup fenomena lain baik persepsi, pemikiran, kemauan dan keyakinan subjek tentang suatu yang transenden, disamping dialog antar agama dalam buku bertajuk fiqih lintas agama adalah dialog teologis. Dialog teologis tidak bisa diabaikan apabila kita ingin melahirkan hubungan antar agama yang sejati, yang melahirkan persahabatan yang sejati juga (Winarno Surachmat, 1995).

Phenomenologi diartikan sebagai penarikan kesimpulan dengan menggunakan tiga langkah, yaitu interpretasi, ekstrapolasi dan pemaknaan. Penafsiran (interpretasi) dimaksudkan mencari latar belakang, konteks materi yang ada agar dapat dikemukakan konsep atau gagasan yang jelas. Ekstrapolasi dimaksudkan untuk mengungkapkan sesuatu dibalik yang tersajikan. Disini materi yang disajikan dilihat tidak lebih dari indikator bagi sesuatu yang lebih jauh lagi. Sedangkan dengan pemaknaan dimaksudkan menjangkau yang etik dan yang transedental dari apa yang disajikan. Dalam memberikan pemaknaan serta penafsiran atas data yang ada pada umumnya bersifat kesejarahan. Pendekatan ini penulis gunakan untuk mengkaji konsep pendidikan multikultural yang sarat dengan nilai pendidikan Islam (Noeng Muhadjir, 1996).

\section{KONSEP PENDIDIKAN MULTIKULTURAL DI INDONESIA}

Istilah pendidikan multikultural secara etimologis berasal dari dua term yakni pendidikan dan multikulturtal. Pendidikan dapat diartikan sebagai proses pengembangan sikap dan tata laku seseorang atau sekelompok orang dalam usaha mendewasakan manusia melalui upaya pengajaran, pelatihan, proses, perbuatan, dan cara-cara yang mendidik. Sedangkan istilah multikultural sebenarnya merupakan kata dasar yang mendapat awalan. Kata dasar itu adalah kultur yang berarti kebudayaan, kesopanan, atau pemeliharaan sedang awalannya adalah multi yang berarti banyak, ragam, aneka. Dengan demikian multikultural berarti keragaman budaya, aneka, kesopanan, atau banyak pemeliharaan. Namun dalam tulisan ini lebih diartikan sebagai keragaman budaya sebagai ejawantah dari keragaman latar belakang seseorang.

Sebelum membicarakan pendidikan multikultural terlebih dahulu kita harus paham mengenai tinjauan studi kultural mengenai pendidikan yang melihat proses pendidikan tidak terlepas dari proses pembudayaan. Tinjauan kultural adalah sebuah alur pemahaman yang mengacu pada konsep budaya dan permaslahannya. Oleh karena itu dalam memahami apa dan bagaimana pendidikan multikultural, paling tidak kita harus tahu batasan yang masuk dalam wilayah budaya.

Pendidikan multikultural adalah sebuah tawaran model pendidikan yang mengusung ideologi yang memahami, menghormati, dan menghargai harkat dan martabat manusia di manapun dia berada dan dari manapun datangnya (secara ekonomi, sosial, budaya, etnis, bahasa, keyakinan, atau agama, dan negara). Pendidikan multikultural secara inhern merupakan dambaan semua orang, lantaran keniscayaannya konsep “memanusiakan manusia”. Pasti manusia yang menyadari kemanusiaanya dia akan sangat membutuhkan pendidikan model pendidikan 
multikultural ini. H.A.R Tilaar dalam bukunya Pendidikan dan Kekuasaan mendefinisikan pendidikan multikultural merupakan suatu wacana lintas batas yang mengupas permasalahan mengenai keadilan sosial, musyawarah, dan hak asasi manusia, isu-isu politik, moral, edukasional dan agama. Ainurrofiq Dawam (2003) dalam bukunya emoh sekolah mendefinisikan pendidikan multikultural adalah proses pengembangan seluruh potensi manusia yang menghargai pluralitas dan heterogenitas sebagai konsekuensi keragaman budaya etnis, suku, dan aliran (agama). Menurut Zubaedi (2004) pendidikan multikultural merupakan sebuah gerakan pembaharuan yang mengubah senua komponen pendidikan termasuk mengubah nilai dasar pendidikan, aturan prosedur, kurikulum, materi pengajaran, struktur organisasi dan kebijakan pemerintah yang merefleksikan pluralisme budaya sebagai realitas masyarakat Indonesia. Memperhatikan berbagai pengertian pendidikan multikultural tersebut, maka dapat diambil beberapa pengertian bahwa pendidikan multikultural adalah sebuah proses pengembangan yang tidak mengenal sekat-sekat dalam interaksi manusia. sebagai wahana pengembangan potensi, pendidikan multikultural adalah pendidikan yang menghargai heterogenitas dan pluralitas, pendidikan yang menjunjung tinggi nilai kebudayaan, etnis, suku, aliran (agama).

Krisis yang Selama ini menjadi permasalahan yang menjadi bahan perbincangan masyarakat umum, masyarakat akademik, masyarakat pejabat marak membicarakan berbagai krisis multidimensi mulai krisis moneter yang menggerogoti masalah ekonomi, krisis moral yang menggerogoti masalah bejatnya mentalitas penguasa dan masyarakat kita, krisis intelektual yang menggambarkan betapa merosotnya strata pendidikan kita, dan lain-lain yang tentunya masih banyak model krisis yang melanda bangsa kita. Menyedihkan memang. yang menimpa masyarakat Indonesia saat ini telah membawa kepada keterpurukan mutu kehidupan bangsa. Keterpurukan tersebut diindikasikan pula oleh merosotnya mutu sumber daya manusia Indonesia yang semakin rendah dan semakin merosot. Kemerosotan tersebut menunjukkan pula rendahnya mutu pendidikan Indonesia. Gerakan reformasi untuk membangun masyarakat Indonesia baru, meminta pendidikan yang bermutu serta merata, khususnya output pendidikan kita yang berkualitas. Dalam mewujudkan pendidikan yang berkualitas paling tidak dibutuhkan peran aktif oleh berbagai pihak yakni ; Masyarakat, praktisi pendidikan, pendidik, pemerintah, dan tentu adanya suasana dan kondisi sosial kemasyarakatan yang saling memahami dan menghargai satu sama lain. Suasana dan kondisi sosial kemasyarakatan secara tidak langsung juga sangat mempengaruhi keberhasilan sebuah acuan ataupun kiblat pendidikan. Hingga saat ini arah pendidikan kita masih dalam poros bimbang dalam menentukan sistem pendidikan yang sesuai dengan visi Indonesia dan pengembangan sistem pendidikan nasional.

Masyarakat patut bangga dengan lahirnya UU Sisdiknas No. 20 Tahun 2003. Dengan segala hal-hal yang positif yang dijanjikan oleh undang-undang tersebut, sayang sekali pengaturan mengenai 1 Seperti yang dirumuskan dalam TAP MR-RI No. VII/ MPR/2001 tentang visi Indonesia masa depan dirumuskan sebagai berikut: Visi Indonesia 2020 adalah terwujudnya masyarakat Indonesia yang religius, manusiawi, 
bersatu, demokratis, adil, sejahtera, mandiri, serta baik dan bersih dalam penyelenggaraan negara. keterkaitan yang erat antara kebudayaan dan pendidikan tidak begitu ditonjolkan di dalam undang-undang tersebut. Kecuali di dalam pasal 4 Ayat (1) sedikit disinggung mengenai masalah nilai-nilai kultural dan kemajemukan bangsa. Disisi lain, pendidikan merupakan bagian penting dari kehidupan yang sekaligus membedakan manusia dengan makhluk yang lain. Bagi manusia, belajar merupakan rangkaian kegiatan menuju pendewasaan kearah kehidupan yang lebih berarti. Manusia sebagai mahluk paedagogik ialah makhluk Allah yang dilahirkan membawa potensi dapat di didik dan dapat mendidik, sehingga mampu menjadi Khalifatul Fil Arld ( Khalifah dibumi), pendukung dan pengembang kebudayaan. Manusia di fasilitasi fitrah oleh Allah yang berupa bentuk dan wadah yang dapat diisi berbagai kecakapan dan ketrampilan, yang dapat berkembang sesuai dengan kedudukannnya sebagai mahluk mulia. (Zakiah Darajat, 1996). Istilah pendidikan dalam konteks Islam tertuang dalam berbagai istilah diantaranya al-ta'dib. Menuurt al-Attas istilah yang tepat untuk menunjukkan pendidikan adalah al-ta'dib, konsep ini didukung atau didasarkan pada hadits Nabi saw berikut:

\footnotetext{
"Muhammad (Ibnu Salam) telah menceritakan kepada kita, al-Maharib telah menceritakan kepada kita, ia berkata: Saleh ibn Hayyan berkata: Amir al-Sya'bi telah menceritakan kepadaku, yakni Abu Burdah dari bapaknya, ia berkata: Rasulullah saw. Bersada: Maka didiklah ia dengan didikan yang baik dan ajarlah ia dengan pengajaran yang baik" (HR. Bukhari, 1996).
}

Pendidikan dalam bahasa yang paling mudah dipahami adalah mengajarkan sesuatu kepada peserta didik sebagai konsekuensi logis kehidupan manusia sebagai mahluk sosial, mahluk moral. Menurut Zuhairini pendidikan adalah suatu aktivitas untuk mengembangkan semua aspek kehidupan dan kepribadian manusia yang berjalan seumur hidup (Zuhairini, 1991). Sedangkan menurut Naquib Al attas menyatakan "Education is a process of instilling into human being". Hal senada juga diungkapkan oleh John Dewey (1961). Dari definisi pendidikan diatas dari masing-masing tokoh pendidikan hampir sama mendefinisikan makna pendidikan yakni, lebih pada act untuk mengupayakan kualitas hidup pada ranah kebaikan. Maka dengan merebaknya isu bahwa pendidikan kita selama ini telah mengalami perubahan tujuan pendidikan, memang benar. Pendidikan kita selama ini memang berorientasi pada dunia kerja, perubahan taraf hidup, ajang untuk main gengsi. Oleh karena itu pendidikan multikultural muncul kepermukaan sebagai solusi dalam pemenuhan dan reformasi tujuan pendidikan. Reformasi pada sekte-sekte pendidikan memberikan beberapa model pendidikan antara lain pendidikan Islam Liberal, pendidikan Islam Kritis, pendidikan Islam Multikultural, pendidikan Islam Nondikotomik dan sebagainya Makna pendidikan dalam perspektif pendidikan multikultural adalah mengupayakan seluruh komponen masyarakat untuk dapat memahami, mengerti, menghargai segala kekurangan dan kelebihan masing-masing komponen masyarakat itu sendiri, terlebih pada menghargai perbedaan yang ada.

\section{Sejarah Munculnya Pendidikan Multikultural}

Pendidikan multikultural merupakan fenomena yang relatif baru di dalam dunia 
pendidikan. Sebelum perang dunia II boleh dikatakan pendidikan multikultural belum begitu dikenal. Pendidikan multikultultural sudah tumbuh sejak dekade 60-an bersamaan dengan kebangkitan gerakan-gerakan civil rights sebagai koreksi atas kebijakan de facto yang sangat lama tentang asimilasi kelompok-kelompok minoritas kelompok dalam bejana peleburan kebudayaan dan hal-hal yang bersifat rasial dan crussial issues. Dan sekitar dekade 70-an pendidikan multikultural telah menemukan momentumnya setelah sebelumnya di AS dikembangkan “ Pendidikan Interkultural”. Dengan munculnya berbagai ide-ide jernih tentang pembaruan pendidikan, Pendidikan multikultural dari masa kemasa akan semakin relevan dan timely. Selain itu, pendidikan juga dijadikan sebagai alat politik untuk melanggengkan kekuasaan yang memonopoli sistem pendidikan untuk kelompok tertentu. Dengan kata lain pendidikan multikultural merupakan gejala baru dalam pergelutan umat manusia yang mendambakan persamaan hak, termasuk hak untuk mendapatkan pendidikan yang sama untuk semua orang "Education for All". Dengan mengamati perjalanan sejarah pendidikan multikultural maka penulis menganggap pendidikan multikultural merupakan sebuah aspek dan kajian.

Mengkaji sebuah perjalanan sejarah, paling tidak kita harus memahami istilah yang menjadi main stream tema tersebut. Dalam tema yang cukup baru ini, ada beberapa langkah dalam mengaktualisasi antara lain, memahami dalam berbagai aspek dan kajiannya. Dari segi aspek pendidikan multikultural merupakan sebuah terobosan ide-ide masa depan yang peka akan nilai-nilai perubahan. Sedang dari aspek kajiannya pendidikan multikultural merupakan sebuah disiplin ilmu ataupun cabang ilmu yang mengorientasikan pada aspek budaya dan pendidikan, atau dengan bahasa lain adalah sebuah elaborasi antara norma-norma budaya, adat istiadat dan norma-norma pendidikan. Dalam mamahami konteks sejarah pendidikan multikultural adalah hal yang harus di pahami antara lain Cultural Studies. Dalam perspektif studi kultural, sistem pendidikan merupakan bagian yang terintegrasi dari sistem budaya, sosial, politik, dan ekonomi sebagai suatu keutuhan (H.A.R. Tilaar, 2003: 153). Dalam kaitan ini studi kultural juga mengintegrasikan serta mengelaborasi antara pendidikan dengan budaya. Perubahan dalam bahasa psikologi adalah konversi yakni, perubahan kearah yang lebih baik.

\section{Lahirnya Pendidikan Multikultural di Indonesia}

Istilah pendidikan multikultural menjadi halhal yang terbilang top request di berbagai kalangan. Isu-isu tentang pendidikan multikultural menjadi isu penting, utamanya pasca rangkaian konflik etnik dan agama dalam beberapa tahun terakhir. Isu ini tidak hanya berkaitan dengan problem mengelola konflik, keragaman, dan politik pengakuan akan keberadaan, bahkan juga merambah dunia pendidikan di Indonesia. Di Indonesia adalah sebuah realitas yang match dengan isu-isu pendidikan multikultural. Dengan sebab realitas Indonesia adalah bangsa yang majemuk. Dalam perkembangnnya di Indonesia pendidikan multikultural dipandang dalam praktik kenegaraan belum dijalankan sebagaimana mestinya. Jika kita melihat tonggak sejarahnya munculnya sumpah pemuda yang berusaha menyatukan berbagai gerakan kepemudaan 
antar daerah, misalnya Boedi Oetomo yang didasarkan pada kebudayan jawa, perkumpulanperkumpulan jong java, jong sumatera, jong selebes dan sebagainya menunjukkan kebhinekaan dari masyarakat Indonesia.

Pandangan multikulturalisme dalam masyarakat Indonesia ini dalam praktek kenegaraan belum dijalankan sebagaimana mestinya. Lambang negara kita adalah Bhineka Tunggal Ika, yaitu keragaman dalam kesatuan ternyata yang ditekankan ialah kesatuannya dan mengabaikan keragaman budaya dan masyarakat Indonesia. Kejatuhan Orde baru menunjukkan reaksi masyarakat terhadap praktik hidup kenegaraan Bangsa Indonesia adalah bangsa yang majemuk dalam berbagai hal yakni, budaya, bahasa, adat istiadat dll. Kemajemukan menurut penulis adalah sebuah keunikan dan kebanggan yang dimiliki bangsa Indonesia yang mungkin juga merupakan aset yang sangat besar bagi masyarakat Indonesia. Ternyata masyarakat kita ingin menunjukkan identitasnya sebagai masyarakat yang berbhineka tunggal ika yang selama orde baru telah ditindas dengan berbagai cara demi untuk mencapai kesatuan bangsa. Demikian pula, praksis pendidikan sejak kemerdekaan sampai era orde baru telah mengabaikan kekayaan kebhinekaan kebudayaan Indonesia yang sebenarnya merupakan kekuatan dalam suatu kehidupan berdemokrasi.

Dalam era yang serba demokrasi, masyarakat akademisi pada khususnya diharapkan mampu untuk merealisir apa-apa yang menjadi crussial issue ataupun arah dari pada pendidikan multikultural. Selain itu kesadaran masyarakat juga sangat mendukung sebagai bukti bahwa indonesia saat ini memang membutuhkan sebuah terobosan dalam sistem pendidikan yang nantinya akan mampu untuk mediator dalam berbagai isuisu keberagaman masyarakat. Selain itu bukti konkrit bahwa di Indonesia sudah mengenal multikultural adalah semenjak dipublikasikannya kemerdekaan Indonesia tanggal 17 Agustus 1945 secara konstitusioanal masyarakat Indonesia menyimbolkan Bhineka Tunggal Ika yang berarti walaupun masyarakat Indonesia terdiri dari bermacam-macam suku, budaya, agama, kepercayaan numun satu pada induk kenegaraan yakni Indonesia.

\section{Orientasi Pendidikan Multikultural}

Pendidikan multikultural yang mencoba mengantisipasi berbagai perbedaan dari yang hanya sekedar berbeda, berhadapan, bertolak belakang/ berpisahan sampai yang saling berlawanan. Pluralitas dan heterogenitas sebagai sebuah realitas tidak dapat dipungkiri dan tidak dihilangkan dari eksistensinya didunia ini. Bisa dikatakan bahwa heteroenitas dan pluralitas adalah sebuah hukum alam (natural law). Sebagai hukum alam, eksistensinya tidak dapat digugat lagi sama sekali. Dan disini tugas manusia adalah mengatur berbagai perbedaan tersebut. Pendidikan multikultural sebagaimana telah dijelaskan di atas, merupakan sebuah pendidikan alternatif yang menjunjung tinggi dan menghargai perbedaan. Karena itu model pendidikan seperti ini diharapkan memiliki orientasi yang jelas, yang memihak pada realitas masyarakat yang majemuk. Hal ini dimaksudkan agar dalam perjalanan sejarah pendidikan multikultural nantinya tidak kehilangan arah atau bahkan berlawanan dengan niali-nilai dasar multikulturalisme. Selain itu 
ada beberapa orientasi pendidikan multikultural juga memiliki arah kemana pendidikan ini dapat diterapkan: Pertama, Orientasi kemanusiaan. Dalam mendeskripsikan kata kemanusiaan, paling tidak kita memahami kata manusia, Kata manusia dalam perspektif akademik adalah sebuah tanda kesempurnaan mahluk diantara berbagai mahluk. Kemanusiaan atau humanisme merupakan sebuah nilai kodrati yang menjadi landasan sekaligus tujuan pendidikan (Quraish Shihab, 2003: 278-279). Tujuan pendidikan dalam bahasa multikultural mencakup dua tujuan yakni, Pendidikan yang bertujuan untuk menguasai ilmu pengetahuan dan teknologi dan pendidikan yang bertujuan untuk membentuk karakter (Character Building). Dalam kaitannya dengan term ini, kiranya tujuan yang kedua yang harus menjadi sasaran pendidikan. Tujuan pendidikan dalam hal ini adalah membantu anak didik memiliki kesadaran, sikap dan prilaku yang menghargai kemajemukan. Kompleksitas problematika dalam pendidikan multikultural inilah yang mengantarkan kata humanisme ini digunakan dengan harapan orientasi kemanusiaan ini mampu menjawab tantangan tehnis dan aplikasi pendidikan multikultural dalam pendidikan islam.

Kedua, Orientasi kebersamaan. Kebersamaan atau Cooperativisme merupakan sebuah nilai yang sangat mulia dalam mewujudkan citacita pendidikan multikultural dalam kondisi masyarakat yang serba plural dan heterogen. Dalam mewujudkan kata kebersamaan dalam term ini adalah dengan melaksanakan pendidikan dialogis. Pendeta Martinus Handoko dalam sebuah seminar bertajuk bedah buku "Pendidikan Pluralisme di Indonesia“ menyampaikan empat hal yang mungkin mampu mewujudkan konsep pendidikan multikultural yakni, pendidikan nilai, mengembangkan logika pluralitas, mengembangkan toleransi maksimal dan pendidikan dialogis (Ainurrafiq Dawam, 2003: 106). Dengan menyelenggarakan keempat solusi diatas Martinus berpendapat bahwa Pendidikan Pluralisme ataupun pendidikan Multikultural nantinya akan mampu menjembatani dan menciptakan pendidikan yang mampu mewujudkan masyarakat yang majemuk, yang demokratis dan berkembang. Ketiga, Orientasi proporsional. Ketika kita berbicara tentang adil, maka sering adil diartikan profesional dan proporsional. Proporsional dalam orientasi pendidikan multikultural adalah merupakan nilai yang di pandang dari aspek apapun adalah sangat tepat. Ketepatan disini tidak diartikan sebagai ketepatan yang bersifat rigid dalam arti hanya menggunakan salah satu pertimbangan, misalnya pertimbangan kualitas intelektual, atau kuantitasnya, melainkan ketepatan yang ditinjau dari semua sudut pandang, khusunya yang berkaitan dengan nilai-nilai proporsional, sehingga berbagai kalangan mampu menerima dengan lapang dada. Orientasi seperti inilah yang diharapkan akan menjadi pilar pendidikan multikultural.

Keempat, Orientasi pengakuan terhadap pluralitas dan heterogenitas. Pluralitas dan heterogenitas merupakan sebuah kenyataan yang tidak mungkin ditindas secara fasis dengan memunculkan sikap fanatisme terhadap sebuah kebenaran yang diyakini oleh sekelompok orang. Pemaksaan kehendak untuk menerima pendapat, pemikiran, teori, kebijakan, sistem pendidikan, ekonemi, sosial dan kebijakan politik adalah tidak sesuai dengan pendidikan multikultural. Karena bila sikap-sikap tersebut tidak doeliminir, maka penghilangan generasi suatu kelompok sampai 
yang tak berdosapun akan sering muncul, apalagi didaerah-daerah konflik. Penghapusan nilai-nilai ethnik, penganut agama (keyakinan), kelompok masyarakatatau bahkan penghilangan negara tertentu menjadi fenomena yang biasa dan wajar. Padahal semua itu jelas-jelas bertentangan dengan nilai-nilai kemanusiaan sebagai orientasi utama pendidikan multikultural. Kelima, Orientasi anti hegemoni dan dominasi. Dominasi dan hegemoni adalah dua istilah yang sangat populer bagi kaum tertindas. Hanya saja kedua istilah tersebuut tidak pernah digunakan atau bahkan dihindari jauhjauh oleh pra pengikut faham liberalis, kapitalis, globalis, dan neo liberalis. Hegemoni bukan hanya dibidang politik, melainkan juga dibidang pelayanan terhadap masyarakat"pendidikan". Karena dewasa ini, yang menjadi penguasa dan menjadi perhatian utama adalah kaum borjuis.

Model interaksi sosial yang demikian inilah yang diharapkan dibangun dalam bidang pendidikan multikultural. Orientasi-orientasi tersebut, tentunya berangkat dari hakikat ontologis pendidikan multikultural sendiri. Keterkaitan antara hakikat dan orientasi perlu terus dijaga dan diupayakan keberadaannya, sebab kesenjangan yang selama ini terjadi disebabkan adanya kesenjangan antara slogan pendidikan yang mampu mengentaskan seluruh eksploitasi yang sangat luar biasa dan besar-besaran. Sampaisampai daerah konflik yang sering diekspos dimedia adalah realitas yang sudah tidak asing ditelingan masyarakat. Sebut saja Aceh, Poso, Ambon, Madura. Contoh kecil adalah ketika penulis menyaksikan recording video amatir tragedi poso, disana akan nampak betapa rasa emosi selalu merajai dan mengendalikan masyarakat yang memiliki kecenderungan untuk menumpahkan darah dengan cara apapun. manusia itu sendiri tereduksi didalamnya tanpa mampu keluar dari lingkaran setan (The satanic circle) modernisasi dan liberal.

\section{Pendidikan Multikultural Sebagai Pendidikan Alternatif}

Undang-undang No. 20 tentang Sistem pendidikan Nasional tersebut, khususnya pasal 28 ayat 2 , telah mengindikasikan bahwa sekolah pada saat itu ditengarai hanya merefleksikan dan menggemakan stereotip dan prasangka antarkelompok yang sudah terbentuk dan beredar dalam masyarakat, tidak berusaha menetralisir dan mengeliminasinya. Bahkan juga mengindikasikan bahwa sekolah ikut mengembangkan prasangka dan mengeskalasi ketegangan antarkelompok melalui perundang-undangan itu yang mengotakngotakkan41 penyampaian pendidikan agama. Salah satu kondisi kehidupan masyarakat yang tidak bisa dihindari ataupun disangkal adalah kenyataan bahwa setiap orang berbeda dari yang lain. Tidak pernah ada dua orang yang sama dalam segala hal, meski mereka dilahirkan dari orang tua yang sama. Kemajemukan adalah suatu kenyataan hidup yang harus diterima. Kemajemukan ataupun pluralitas menurut Ulil Abshar Abdala merupakan bagian dari sunatullah (M. Imdadun Rahmat 2003).

Melihat demografi dan peta masyarakat Indonesia yang notabenenya terdiri dari berbagai budaya, bermacam adat, beragam bahasa. Dalam hal ini pendidikan multikultural berperan sebagai pendidikan alternatif yang tetap menghargai keberagaman diatas dengan memperhatikan konsekuensi dan berpedoman pada Bhineka Tunggal Ika. Jika kita tengok lagi berbagai konflik bernuansa SARA yang terjadi beberapa tahun silam 
tentunya akan kita temukan sebuah kesimpulan bahwa keberhasilan sebuah sistem pendidikan dipertanyakan. Secara spesifik pendidikan memiliki peran vital dalam upaya menjalin keragaman dan menghilangkan sekat-sekat dalam agama. Prospek pendidikan multikultural di Indonesia jika dilihat dari poros budaya secara lahiriyah dapat dikatakan akan menemukan titik cerah jika kesadaran akan heterogenitas mulai ditanamkan sejak dini. Agenda sebuah tatanan pendidikan multikultural adalah menciptakan dan pembentukan moral bangsa yang mampu memahami dan mengerti akan eksistensi sosio masyarakat yang ada.

Selain itu, pendidikan multikultural juga memberikan alternatif yang berupa diskursusyang sangat berkaitan dengan pendidikan multikultural. Dalam buku Kekuasaan dan Pendidikan Tilaar memberikan gambaran tiga lapis diskursus yakni: Pertama, Masalah Kebudayaan. Dalam hal ini terkait maslah-masalah mengenai identitas budaya suatu kelompok masyarakat atau suku. Bagaimanakah hubungan antara kebudayan dengan kekuasaan dalam masyrakat sehubungan dengan konsep kesetaraan di masyarakat. Apakah kelompok-kelompok dalam masyarakat mempunyai kedudukan dan hak yang sama dalam keempatan mengekspresikan identitasnya di masyarakat luas. Kedua, Kebiasaan-kebiasaan, tradisi, pola-pola kelakuan yang hidup didalam suatu masyarakat. Ketiga, Kegiatan atau kemajuan tertentu (Achievement) dari kelompok-kelompok didalam masyarakat yang merupakan identitas yang melekat pada kelompok tersebut. Dengan tiga lapis diskursus ini diharapkan pendidikan multikultural akanmampu untuk mampu memberikan alternatif sebagai pemenuhan sebuah sistem pendidikan.

\section{Membaca Kurikulum Pendidikan Multikultural}

Membicarakan tentang kurikulum maka paling tidak kita berbicara dengan kebutuhan masyarakat. Kebutuhan masyarakat dalam era multikultural adalah otonomi pendidikan dan tentunya pada kurikulum yang berorientasi pada nilai-nilai budaya. Hal ini berarti diperlukan ahli-ahli kurikulum dengan pengetahuan yang luas mengenai kebudayan daerah dan kebudayaan nasional. Para pakar inilah yang menyusun bentuk dan isi pendidikan multikultural dalam berbagai bentuknya. Hendaknya pendidikan multikultural juga mendasari dan menjiwai semua mata pelajaran di dalam lembaga pendidikan formal dan informal. Sesuai dengan lembagalembaga pendidikan sebagai pusat kebudayaan maka keseluruhan jiwa dan kegiatan lembagalembaga pendidikan kita didasari oleh nilai-nilai multikulturalisme.

H.A.R Tilaar dalam bukunya bertajuk Kekuasaan dan Pendidikan menyebutkan tiga sumber untuk mencapai kurikulum pendidikan multikultural yakni konsep mengenai kebutuhan peserta didik, konsep mengenai kebutuhan masyarakat, dan konsep mengenai peranan dan status mata pelajaran yang akan disampaikan. Dari ketiga konsep itulah rumusan kurikulum pendidikan multikultural akan terbentuk. (H.A.R. Tilaar, 2003). Menurut Hamid Hasan, Pengembangan kurikulum dengan menggunakan pendekatan pengembangan multikultural harus didasarkan pada prinsip: 1) keragaman budaya menjadi dasar dalam menentukan filsafat; 2) keragaman budaya menjadi dasar dalam mengembangkan berbagai komponen kurikulum seperti tujuan, konten, proses, dan evaluasi; 3) 
budaya di lingkungan unit pendidikan adalah sumber belajar dan objek studi yang harus dijadikan bagian dari kegiatan belajar siswa; dan 4) kurikulum berperan sebagai media dalam mengembangkan kebudayaan daerah dan kebudayaan nasional. Sesuai prinsip pendidikan multikultural, maka aktivitas pembelajaran di sekolah disarankan untuk memberi perhatian pada kompleksitas yang dinamis dari berbagai faktor yang mempengaruhi interaksi manusia, seperti fisik, mental, kemampuan kelas, jender, usia, politik, agama, dan etnisitas.

Untuk itu langkah-langkah yang ditempuh untuk mengembangkan model pembelajaran pendidikan multikultural adalah sebagai berikut: Pertama, guru mereduksi atau mengikis sikap negatif yang mungkin mereka miliki terhadap pluralisme sosial, keagamaan, dan etnis. Kedua, seorang pendidik dan anak didik melakukan analisa terhadap situasi agar akrab dengan masyarakat. Ketiga, seorang pendidik dan anak didik memilih materi yang relevan sekaligus menarik. Keempat, seorang pendidik dan anak didik, bersama-sama menyelidiki persoalan yang berkaitan dengan materi yang dipilih. (Zubaedi, 2004). Selain itu dalam mengaktualisasikan nilainilai multicultural dalam pendidikan diperlukan juga jalur yakni kurikulum yang mampu memahami kondisi masyarakat pendidikan. Jadi dengan terealisasinya pendidikan multikural yang berdasarkan pemahaman atas perbedaan, dan juga yang mengorientasikan pada subjek didik maka, kekhawatiran akan munculnya predikat dar al harb mampu kita hilangkan dan menggantinya dengan dar al salam. Tidak hanya itu kesadaran untuk saling menghargai dan memahami sisi kekurangan individu dan masyarakatpun akan teraktualisasi.

\section{KESIMPULAN}

Pendidikan multikultural adalah proses pengembangan seluruh potensi manusia yang menghargai pluralitas dan heterogenitasnya sebagai konsekuensi keragaman budaya etnis, suku, dan aliran (agama). Pendidikan Multikultural merupakan Model pendidikan yang menawarkan konsep persamaan, menghargai dan menghormati pluralitas dan heterogenitas, menghargai keragaman (budaya, agama, suku, bangsa, etnis). Pendidikan yang secara menyeluruh membongkar kekurangan, kegagalan dan praktikpraktik diskriminatif dalam proses pendidikan. Pendidikan multikultural sarat dengan nilainilai kemanusiaan, nilai-nilai sosial, nilai-nilai kealaman, dan nilai-nilai ketuhanan. Pendidikan multikultural merupakan sebuah solusi abstraktif dalam rangka mengeliminir segala kemungkinan terburuk mengenai lingkup multikultural.

\section{DAFTAR PUSTAKA}

Abdullah, Amin. (2003). Agama dan Kerukunan. Harmoni "Jurnal Multikultural dan Multireligius". Vol.II .No.5.

Al-Ghulayani, Musthafa. (1953). Idhah alNasihin. Pekalongan: Rajamurah.

AR., Muhammad. (1996). Pendidikan di alaf baru "Rekonstruksi atas moralitas pendidikan". Jakarta: Persada.

Arikunto, Suharsimi. (1989). Prosedur Penelitian "Suatu Pendekatan Praktik". Jakarta: Bina Aksara.

Darajat, Zakiah, dkk. (1996). Ilmu Pendidikan Islam. Jakarta: Bumi Aksara kerja sama DEPAG RI. 
H.A.R. Tilaar. (2003). Kekuasaan dan pendidikan "Suatu tinjauan dari perspektifstudi cultural. Magelang: Indonesiatera.

Hamka. (1990). Tafsir AlAzhar (Jil.9.). Singapura: Pustaka Nasional.

Imam Bukhari. (1996). Sahih Bukhari (Juz I.). Beirut: Dar al-Fikr.

Langgulung, Hasan. (2000). Asas-asas Pendidikan Islam. Jakarta: PT. Al Husna Zikra.

Marimba. (1989). Pengantar Filsafat Pendidikan Islam. Bandung: Al Ma'arif.

Muhadjir, Noeng. (1995). Metodologi Penelitian Kualitatif (Edisi I.). Yogyakarta: Rake Sarasin.

Muzairi. (2002). Eksistensialisme Jean Paul Sartre; Sumur Tanpa Dasar Kebebasan Manusia. Yogyakarta: Pustaka Pelajar.

Nata, Abudin. (2002). Metodologi Studi Islam. Jakarta: PT. Raja Grafindo Persada.

Nurdin, Muhammad. (2004). Kiat menjadi Guru Profesional. Yogyakarta: Prismasophie.

Rahmat, M. Imdadun. (2003). Islam Pribumi "Mendialogkan Agama Membaca Realitas" (et.al). Jakarta: Erlangga.
Rimbun, Masri Singa dan Efendi, Jufri. (1982). Metode Penelitian Survey. Jakarta: LP3ES.

Sartre, Jean Paul. (2002). Eksistensialisme dan Humanisme (Yudhi Murtanto, Penerjemah.). Yogyakarta: Pustaka Pelajar.

Shihab, M.Quraish. (2003). Tafsir Al Misbah V. 13. Jakarta: Lentera Hati. . (2003). Wawasan Al Qur'an. Bandung: Mizan.

Sirry, Mun'im A. (2003). Fiqih Lintas Agama "Membangun Masyarakat Inklusif-Pluralis" (ed.). Jakarta: Paramadina.

Walizer, Michael.H. dan Wienier, paul. L. (1991). Metode dan Analisis Penelitian Mencari Hubungan (Arief sukadi sadiman, Penerjemah.). Jakarta: Erlangga.

Zubaedi. (2004). Telaah Konsep Multikulturalisme dan Implementasinya Dalam Dunia Pendidikan. Hermenia Vol.3 No.1, Januari-Juni. . (2004). Multikulturalisme"Tantangantantangan Global Masa Depan Dalam Transformasi Pendidikan Nasional. Jakarta: Grasindo. 